University of Thi-Qar Journal Vol.10 No.1 Mar 2015

Web Site: https://jutq.utq.edu.iq/index.php/main Email: journal@jutq.utq.edu.iq

The Concept of Nature in Thomas Hardy's Short Poems

https://doi.org/10.32792/utq/utj/vol10/1/11

Anssam Ali Flefil Al-Husseinawy

University of Thi-Qar College of Education Department of English

\begin{abstract}
The subject of this paper is the concept of nature in Thomas Hardy's short poems. By the word "nature," it is intended to refer to every thing in the cosmos, including living creatures such as plants and animals or in some cases elements associated with inanimate objects. The researcher would like to explain that this concept, according to Hardy (1840-1928), has different connotations such as scene, force, power, character by it self, and inner feelings. Accordingly, the aim of this paper is to shed light upon the meaning of nature in selected short poems of Hardy who tends to be more complicated in his treatment with the concept of our intention because he, in some cases, is referred to as a pessimistic writer.
\end{abstract}

Therefore, our present concern takes an order, which proceeds gradually according to the following sequences: it begins with an introductory note explaining the meaning of nature in general. Then, it depicts Hardy and his treatment of nature, referring to selected short poems of his. These poems are chosen for they are closely related to the term of our target. The researcher, in this paper, tries to focus on rather important poems and to refer to the main verses in others in selecting the following samples: "The Darkling Thrush"(1900), "God-Forgotten"(1902), "Transformations"(1902), "The Voice" (1912), "The Convergence of the Twain"(1913;1914), "A SignSeeker"(1919), "Snow in the Suburbs"(1925),"Winter in Durnover Field"(1928), "Birds at Winter Nightfall"(1928). Many other poems are excluded for questions related to space and time. The paper ends with a conclusion summing up its main findings.

The results reflected Hardy's interest in nature and the natural phenomena of the cosmos. They also presented the writer as a literary figure who had fluctuated view towards nature, according to his mood and the situation in which nature was described. In addition, they revealed Hardy's tendencies towards writing poems concerning, in particular, subjects about winter, birds and sea. All these can be portrayed within Hardy's point of view in which nature is above all and controls Man's ability.

\title{
The Concept of Nature in Thomas Hardy's Short Poems
}




\section{University of Thi-Qar Journal Vol.10 No.1 Mar 2015}

Web Site: https://jutq.utq.edu.iq/index.php/main Email: journal@jutq.utq.edu.iq

Nature is the whole universe and every created thing. It is the force that controls the phenomena of the physical world .It also refers to out doors life without civilization, the simple and primitive life. ${ }^{1}$ In literature, the word has separate connotations according to the period in which it is used and the writer who deals with. Its suitable meaning varies according to the interpretations of the followers of different literary schools. It measures out external nature or internal human one. For example, the 'Romantics' ${ }^{2}$ find in nature a justification for their own dreams and ambitions. Nature also takes a scientific implication especially in the 'Darwinian' ${ }^{3}$ concepts of it and in the natural struggle for existence or survival. ${ }^{4}$ Hence, many writers deal with subjects, including external nature in their works such as "childlike delight" in the open world," a background or setting to the human action or emotion" and nature for its own sake. ${ }^{5}$ Accordingly, many literary figures tackle this term in their career and by it they reveal either outer scenes or inner feelings.

However, Thomas Hardy is an English poet and novelist. He is regarded as a born poet. Even his novels seem to be the work of the poet. He himself considers poetry to be his true vocation in life. ${ }^{6}$ He integrates his love stories into the natural background against which they are set in his literary work. This integration is stressed between Hardy's themes and their natural settings. Moreover, Hardy is one of the first poets to describe nature independently from human themes and purposes. In his novels and poems, one can find three integrated layers(direct human-interest, nature, and the cosmic). ${ }^{7}$

To Hardy, Nature is a broad presence, which often links human life with sadness and fatality. ${ }^{8}$ In "The Voice," the wind's sound becomes confused with the remembered once-loved voice, as the poet stands in a desolate lonely place. In this case, nature reflects inner moods of the speaker himself: ${ }^{9}$

Or is it only the breeze, in its listlessness

Travelling across the wet mead to me here,

You being ever dissolved to wan wistlessness,

Heard no more again far or near?

(11. 9-12)

Hardy is a master of observing pastoral images and stunning landscapes in his poems. ${ }^{10}$ In this respect, he possessed a strong talent for describing what he sees. His discussion of nature offers far more to the reader than a simple statement of emotion. To him, nature is capable of playing a profound role in the emotion of his literary work. In "Winter in Durnover Field," for example, 
Web Site: https://jutq.utq.edu.iq/index.php/main Email: journal@jutq.utq.edu.iq

the poet portrays several natural phenomena such as rain, wind, sky and winter. This natural milieu is revealed through the poem's characters :

(11. 1-10)

Rook-Through the field I find no grain;

The cruel frost encrusts the corn land!

Starling-Aye; patient pecking now is vain

Throughout the field, I find.....

Rook- $\quad$ No grain!

Pigion- Nor will be, comrade, till it rain,

Or genial thawings loose the Iorn land

Rook- I find no grain:

The cruel frost encrusts the corn land! : ${ }^{11}$

Here the poet describes the scene in a pastoral field, recently sown with wheat and frozen to iron hardness. The three large birds or characters fly above this field, and wistfully see the surface wind keen the sky.

Writing in a Post-Darwinian era, Hardy tends to depict nature as an omnipotent but unconscious force that tragically rules human life according to non-human considerations. Thus he inserts a distance of motive and purpose between human and the natural world. ${ }^{12}$ In "Transformations," he describes the transformation of human beings into the natural world when he says," A ruddy human life/ now turned to a green shoot." ${ }^{13}$ He focuses on the cycle of life where he speculates the source of the soul in a small patch of vegetation .He believes in the this circle of life that we are born out of the earth, walk on it as human beings for a while, and finally become part of it once again, when we die. ${ }^{14}$ In this occasion, it is important to mention that Hardy was an agnostic who believes in nothing can be known about God except material things. ${ }^{15}$ Accordingly, nature has the power that controls human action. For instance, in "God-

Forgotten," he makes a kind of interview between him and" the Lord Most High" as he is sent" by the sons of Earth, to win/some answers to their cry." This interview, according to Hardy, reveals the forgetting of God to His creation of the earth and human beings: 
University of Thi-Qar Journal Vol.10 No.1 Mar 2015

Web Site: https://jutq.utq.edu.iq/index.php/main Email: journal@jutq.utq.edu.iq

"The earth, sayest thou?the Human race?

By me created? Sad its lot?

Nay: I have no remembrance of such place:

Such world I fashioned not."- ${ }^{16}$

M.B. Cronin shows that Hardy focuses on folklore as a kind of openness to the power of the supernatural. The poetry of Hardy, as Cronin asserts, expresses the living, literal, intersection of the natural and supernatural in the things and places of this world. He also points out that the character of the speaker in Hardy's poetry agrees that nature is alive with a meaningful, supernatural power. ${ }^{17}$ For example, in" A Sign Seeker," the speaker observes natural occurrences and phenomena with acuity and intensity. This speaker is seen as an avid perceiver who seeks out connections between this world and the next:

I learn to prophesy the hid eclipse,

the coming of eccentric orbs,

to meet the dust the sky absorbs,

to weight the sun, and fix the hour each planet dips. ${ }^{18}$

Hardy is a big fan of nature and a big fan of birds in the natural surroundings. He makes many references to birds in his poems. In "Birds at Winter Nightfall," he uses these birds, as they look at snowflakes, to describe the onset of the snow as "shutting indoors that cromb-outcaster." ${ }^{19}$ They refer to the human beings who own the house they nest around. Thus, they become part of nature and describe it openly. In "Snow in the Suburbs," the author portrays a sparrow that enters the natural scene in the cold weather, and describes the heavier movement of the snow which nearly entombs the bird:

A sparrow enters the tree,

Whereon immediately

A snow-lump thrice his own slight size

Descends on him and showers his head eyes, ${ }^{20}$ 


\section{University of Thi-Qar Journal Vol.10 No.1 Mar 2015}

Web Site: https://jutq.utq.edu.iq/index.php/main Email: journal@jutq.utq.edu.iq

Penetrating deeply, "The Darkling Thrash"21 is considered as a sample poem for Hardy's referring to birds and winter season. In this poem, Hardy describes objects in nature and shows his ability to paint a very sorrowful picture of a dying winter storm in few lines.

He also reflects his capacity as a poet to immortalize this thrush. In addition, he uses images springing from nature to describe his state of mind and feeling at the last Christmas night of the $19^{\text {th }}$ century.

In the first stanza, the poet stands by a gate of a small woodland area, looking at the snow with its grey colour. This atmosphere makes us predict future trouble. The sun at that time was desolate in the coldest worst part of winter season because it is cloudy and misty- winter's dregs:

I leant upon a coppice gate

When frost was spectre- grey

And winter's dregs made desolate

The weakening eye of day ${ }^{22}$

(11. 1-4)

In spite of that, Hardy finds an image in nature or rather in man's relationship with it to express his sense of cosmic emptiness and to reinforce his opinion about the natural world. There was a plant, which was flexible, climbing 'bine-stems that scored the sky' seeming in confused mass stops the sky "like strings of broken lyres, " since it was a Christmas night ,everybody had already sought the fire, leaving the poet alone at this woodland area. Furthermore, the poet keeps on describing the woodland where he finds himself. He says that the land has a sharp feature, which seems to be like the century's corpse, whereas the cloud is the canopy. This canopy is the underground room where the corpse is buried. In this sense, the theme of winter as external circumstance becomes indicative of humane motional state. ${ }^{23}$ The wind is lamenting the death of the century. The old pulse of the birth was declining hard. Here, the stretched-out body of the century is exposed to the "wind."

Most significantly, the poet indicates that every man in this world seems to be "fevourless" and has no warmth of feeling for the century, as if a breathless body comes to an end. The speaker's mood, here, is suggested by his observations of nature along with the cosmos, and not by any direct statement. It is interesting to note that Hardy" in the first two stanzas, employs elements of nature that include the natural world of desolation, which is dying in winter. 


\section{University of Thi-Qar Journal Vol.10 No.1 Mar 2015}

Web Site: https://jutq.utq.edu.iq/index.php/main Email: journal@jutq.utq.edu.iq

Through this atmosphere, nature is going to be shown with little hope because of the entrance of the thrush. This thrush is dark in order to intensify the winter season especially in the last day of the $19^{\text {th }}$ century:

At once a voice arose among

The bleak twigs overhead

In a full-hearted evensong

Of joy illuimited,

The bird is singing his full hearted song. It is chosen to get rid of this growing gloom of the place. It becomes symbol of hope for new life. Although it is "aged," "frail," "gaunt," and "small," it is still capable of hope, even in the bleak winter. Described as having 'chosen thus to fling his soul upon the growing gloom," this bird becomes a metonymy for all nature that struggles and survives the dark despair of winter. ${ }^{24}$

The poem ends with a description of a "caroling" bird (which Hardy uses in other poems to suggest hope and the continuity of life). Hardy uses this bird to reflect a theme in romantic nature poetry; that is nature holds the secrets and the potential for happiness that Man emotionally appreciates. ${ }^{25}$ Although the weather is awful, the speaker hears the singing of the thrush and concludes that it must know of "some blessed Hope, where of he knew" and he "was unaware." So he is more in tune with nature than most people because the song of the bird affects him and gives him some hope. Hardy feels that animals have such a better life style than humans do. They know things by instinct of which human beings could never even conceive. ${ }^{26}$ Yet, Hardy can see no cause for joy; he can only hope that the bird can feel something he himself is unable to perceive. He can be regarded as a poet who longed for, and does not assert the confidence and poetic authority of the romantics. The darkling thrush symbolizes the exhaustion of the romantic aesthetic and the worldview of nature. ${ }^{27}$ The bird's song is, therefore, considered as part of nature.

Consequently, Nature is not only the background to Hardy's poems, but it is also a leading character in them. Nature's role becomes nearly as important as any other character and conveys no less emotion. Sometimes, it is a spiritual agent. ${ }^{28}$ In addition, it is shown as a character itself in the drama of life much the same as the fate which appears in the Greek tragedies; and, for all its beauty, could not hide witless cruelty. ${ }^{29}$ 


\section{University of Thi-Qar Journal Vol.10 No.1 Mar 2015}

Web Site: https://jutq.utq.edu.iq/index.php/main Email: journal@jutq.utq.edu.iq

However, in "The Convergence of the Twain" ${ }^{30}$ (lines on the loss of "Titanic"), Hardy speaks about the fate of a ship which is named Titanic. The poem is a beautiful weaving of nature and technology. It presents the idea that every thing is from earth and will eventually end up back in the earth again. It starts out describing this ship as it is lying miles dawn in the deep sea. Then, it takes a turn to depict the life on the boat and the unknown that waits to happen. The poet discusses objects such as the ship and the iceberg; and he seems to be philosophizing about life. He wants to show that nature will let man do many things, but if he gets too confident in his "Pride to Life" ${ }^{31}$ as the building of such a colossal thing, nature will stop him from being successful:

In a solitude of the sea

Deep from human vanity

And the Pride of Life that planned her, stilly couches she.

Hardy continues describing the mirrors which women used to make themselves beautiful for the ship's dances and dinners. He shows the richness and fortune of this ship, but he puts it in a solemn tense as it places the mirrors on the bottom of the sea, "over the mirrors meant/To glass the opulent/ The sea -worm crawls-grotesque, slimed, dumb, indifferent." Then, he speaks about the jewels of the women, which are now lying in the dark of the sea. Generally speaking, he talks about the people on the ship, who are unaware of the danger ahead. He describes all of the extravagant things on the ship as covered in crawling dumb and indifferent sea worms. He wants to show that Nature does not care for all that glitters in this world and he questions, "What does this vaingloriousness down here?" In fact, Hardy is bringing the theme of fatalism. To him the "Imminent will" can refer to Fate or God, some force above all else. This poem also hints a battle between nature (the iceberg) and the society (the Titanic)in which the iceberg wins: ${ }^{32}$

The immanent Will that stirs and urges everything

Prepared a sinister mate

For her-so gaily great

A Shape of Ice, for the time far dissociates. 


\section{University of Thi-Qar Journal Vol.10 No.1 Mar 2015}

Web Site: https://jutq.utq.edu.iq/index.php/main Email: journal@jutq.utq.edu.iq

Unlike the theme of Man in unity with Nature, the end of the poem suggests the disharmony of nature in conjunction with human life. ${ }^{33}$ The result is the actual destruction of the ship:

On being anon twin halves of one august,

Till the Spinner of the Years

Said 'Now!' And each one hears,

And consummation comes, and jars two hemispheres,

However, Hardy wants to reflect an idea that man should not get cocky because Nature/God/ Fate will come back to bite him. ${ }^{34}$ Finally, the contrast between what was past and what will expected, is asserted thoroughly in nature's role.

To conclude, it is clear that our present concern presents Hardy as a writer who uses nature in its beautiful and wild faces. Hence, the thorough analysis of his short poems stresses the author's interest in nature. The paper reveals Hardy's indulgence in referring to birds in the natural surroundings of his poems. To him, the bird becomes a symbol for beauty, cruelty of nature and hope. He makes many references or allusions to birds in his literary career, for example, "The Darkling Thrush," "Snow in the Suburbs" and "Birds at Winter Nightfall." The study also reflects the author's tendency in describing the bleakness of winter and the hardship of nature to display internal feelings or external milieu. This is shown in several poems as "Winter in Durnover Field," "Snow in the suburbs," "The Darkling Thrush" and " The Convergence of the Twain."

Nature, to Hardy, can be depressing as hell at times like "The Convergence of the Twain," and can be rather beautiful at other times as " birds at Winter Nightfall." Thus, he seems to have an ambivalent attitude towards it. He utilizes it not just as a decoration but also as a function since it is not all the flowers of nature inspire him and should be celebrated in his writings. In addition, he uses his mediations on the nature scenes to contemplate serious issues like life itself. Moreover, one can see that in Hardy's nature poems, Man is depicted as the smallest of insects, which possess Knowledge far beyond that of Man.

In the light of the foregoing discussions and findings, Hardy's "The Darkling Thrush," for example, reflects the poet question about what life in nature means. The reader is left to fall back on the puzzles for understanding the 


\section{University of Thi-Qar Journal Vol.10 No.1 Mar 2015}

Web Site: https://jutq.utq.edu.iq/index.php/main Email: journal@jutq.utq.edu.iq

meaning of nature to man. However, the poet speaks not of every person upon earth, but about every spirit that seems to be fevourless. Undoubtedly, the character of the speaker of the poem of our target sees nature as alive with influence and power.

The poems that are mentioned in this paper filter the revolution of the setting of the external world. Hence, the objects, which are described by Hardy, possess personality and emotion. In this natural world the human can be educated by nature's constant wishing for rebirth. At least, the short poems, in this paper, portray certain themes the freedom that nature offers in contrast with society and the ability of man to find personal clarity while reflecting serenity of nature. In addition, one tends to see that Hardy wants to show the unity of man with nature in the point that the latter is a sort of divine teacher for the former through controlling his action.

\section{Notes}

1J.A. Simpson and E.S. C.Weiner, "Nature," in The Oxford English Dictionary,Vol. IX, 2nd edition(Oxford: Oxford University Press, 1989), pp.570-571.

2 'The Romantics' are those who belong to the Romantic Movement. This movement is defined as an artistic and intellectual movement, originating in Europe in the late 18th century and characterized by heightened interest in nature, emphasis on the individual's expression of emotion, departure from the attitudes and forms of classicism, and rebellion against established social rules and conventions. See C. Hugh Holman, "Nature," in A Handbook to Literature ( New York: The Bobbs-MerrillCo., Inc., 1980),pp.392-394.

3'Darwinian' refers to those who believe in the ideas of Charles Darwin (18091882) whose theory of evolution involves the following: species have great fertility and they make more offspring than can grow to adulthood. Populations remain roughly the same size, with modest fluctuations. Food resources are limited, but are relatively constant most of the time. There is struggle for existence and survival among individuals. In sexually reproducing species, generally, no two individuals are identical. See Paul Edwards, ed., "Darwinism," in The Encyclopedia of Philosophy (New York: The Macmillan Co. and Free Press, 1067), p.119.

4 Holman, "Nature," in A Handbook to Literature, pp. 288-291.

5Ibid.

6T.R.M. Creighton, "Introduction," in Thomas Hardy: Poems, edited by T.R.M. Creighton (London: Macmillan, 1974), p.7. 


\section{University of Thi-Qar Journal Vol.10 No.1 Mar 2015}

Web Site: https://jutq.utq.edu.iq/index.php/main Email: journal@jutq.utq.edu.iq

7F.B. Pinion, Hardy the Writer: Surveys and Assessment,(London:Macmillan Press, 1990), pp.255-256.

8 Edmund Coosse, "Mr. Hardy's Lyrical poems," in Thomas Hardy: the Critical Heritage, edited by R.G.Cox(London: Routledge and Kegan Paul, 1970),p 457.

9 Thomas Hardy, "The Voice," in Cambridge Book of English Verse 1900-93, edited by Allen Freer and John Andrew (London: Cambridge University Press, 1970), p.17.

10Anne Sharp, "Hardy's Whisper: The Pathetic Fallacy in Far From the Madding Crowed" in Hardy's Miscellany, Vol.V,(2003.URL :http//www.Hardy Miscellany.).

11 Thomas Hardy, "Winter in Durnover Field," in Thomas Hardy; poems, edited by T.R.M Creighton, p.13.

12 Karl Kroeber "Religious Relation; Nature Sex, and Tragedy in the Novels of both Thomas Hardy and the Early Writings of D.H. Lawrence," published

dissertation,(1990.URL:http//www.digitalcommons.libraries.columbia.edu/diss ertations/)March).

13 Quoted in Kelly Cleaverger, "Students Impression Papers on Hardy'sNaturePoetry,"

(2006.URL:http//www.gettysburg.edu/sflvnn/teaching/THnaturepoetry.htm/.).

14 Ibid.

15 Pinion,p.251.

16Thomas Hardy, "God Forgotten," in The Literature of England, edited by K. Anderson and W.E.Buckler(New York: Scott Foresman and Com.,1967),p.1183.

17M.B. Cronin, "Earth old Grouping 'the Natural World and Percipience in the Writings of both Hopkins and Thomas Hardy,"' published dissertation(2001.URL::http//www.gerardmanleyhopkins.org/).

18Quoted in Ibid.

19Quoted in Cleaverger, "Students Imperssion Papers on Hardy's Nature Poetry."

20Thomas Hardy , "Snow in the Suburbs," in the Literature of England,edited by K. Anderson and w.E.Buckler, p.1186. 


\section{University of Thi-Qar Journal Vol.10 No.1 Mar 2015}

Web Site: https://jutq.utq.edu.iq/index.php/main Email: journal@jutq.utq.edu.iq

21"The Darkling Thrush" is originally entitled "By the century's Death-Bed." The date of this poem is 31st December 1900. In fact, it watches the sun set on one century and down on another. See Jedi Bix 783,"everything: The Darkling Thrush," (April 2002.URL:http//everything2.com/index).

22 All quotations concerning the lines of "The Darkling Thrush" are taken from: Thomas Hardy, "The Darkling Thrush," in The Literature of England, pp.1182-1183.

23 Cleaverger.

24 Jedi Bix 783,"Everything: The Darkling Thrush."

25Cleaverger.

26 Ibid.

27James K. Chadler, "Turning the Century With Thomas Hardy," (2004. URL:http//www.fathom.lib.Uchicago/).

28Coosse,"Mr. Hardy's Lyrical poems,"p.457.

29 Pinion, p.174.

30 Hardy's poem, written in 1913 and included in Satires of Circumstance(1914), is undoubtedly the best work to have been inspired by the disaster, the circumstance of the event fit beautifully into his fatalistic philosophy. See Anderson and Buckler,(eds.),p.1185.

31All quotations concerning the lines of "The Convergence of the Twain," are taken from Thomas Hardy, the Convergence of the Twain," in The Oxford Book of Twentieth -Century English Verse, edited by Philip Larkin(London:OxfordUniversity Press,1973),pp.8-9.

32Cleaverger.

33 Ibid.

34 Ibid.

\section{Bibliography}

Chadler, James K. "Turning the Century with Thomas Hardy."2004. URL: http//www.fathom.lib.Uchicago/. 


\section{University of Thi-Qar Journal Vol.10 No.1 Mar 2015}

Web Site: https://jutq.utq.edu.iq/index.php/main Email: journal@jutq.utq.edu.iq

Cleaverger ,Kelly. "Students Imperssion Papers on Hardy's Nature

Poetry,"2006.URL

:http//www.gettysburg.edu/sflvnn/teaching/THnaturepoetry.htm/.

Coosse, Edmund. "Mr. Hardy's Lyrical poems." In Thomas Hardy: the Critical Heritage. R.G.Cox(ed.)London: Routledge and Kegan Paul, 1970.

Creighton,T.R.M.Ed.Thomas Hardy :Poems. London :Macmillan, 1974.

Cronin, M.B. "Earth old Grouping ' the Natural World and Percipience in the Writings of both Hopkins and Thomas Hardy,'" published dissertation.2001.URL: :http//www.gerardmanleyhopkins.org/

Edwards,Paul .Ed. "Darwinism." In The Encyclopedia of Philosophy. New York: The Macmillan Co. and Free Press, 1967.

Freer, Allen and John Andrew .Eds. English Verse 1900-93.London:

Cambridge University Press, 1970.

Holman, C. Hugh. "Nature." In A Handbook to Literature. New York:The Bobbs-MerrillCo.,Inc., 1980.

Jedi Bix 783."Everything: The Darkling Thrush." April 2002.URL:http//everything2.com/index.

Kroeber, Karl. "Religious Relation; Nature, Sex, and Tragedy in the Novels of both Thomas Hardy and the Early Writings of D. H. Lawrence, , published dissertation.1990.URL:http//www.digitalcommons.libraries.columbia.edu/disse rtations/.

Larkin, Philip .Ed. The Oxford Book of Twentieth -Century English Verse .London: Oxford University Press, 1973.

Pinion, F. B. Hardy the Writer: Surveys and Assessment. London: MacmillanPress, 1990.

Sharp, Anne. "Hardy's Whisper: The Pathetic Fallacy in Far From the Madding Crowed." In Hardy's Miscellany. Vol.V.2003.URL: http//www.Hardy Miscellany.

Simpson, J.A. and E.S. C.Weiner."Nature."In The Oxford English Dictionary. Vol. IX, $2^{\text {nd }}$ edition. Oxford: Oxford University Press, 1989.

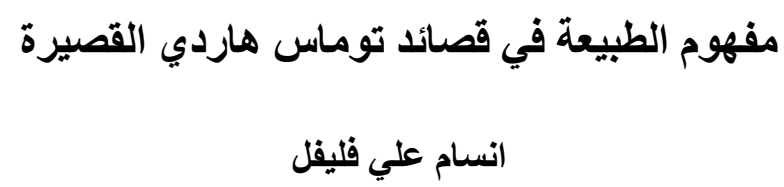




\section{University of Thi-Qar Journal Vol.10 No.1 Mar 2015}

Web Site: https://jutq.utq.edu.iq/index.php/main Email: journal@jutq.utq.edu.iq

$$
\text { جامعة ذي قار / كلية التربية للعلوم الانسانية }
$$

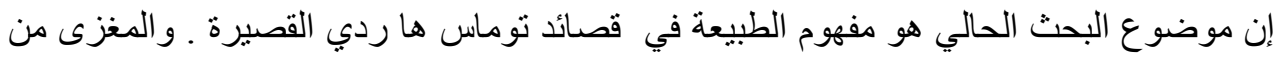

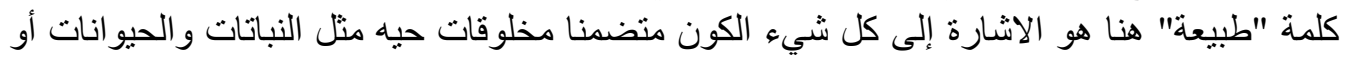

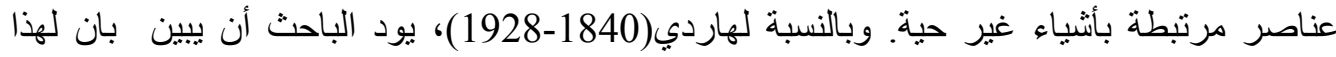

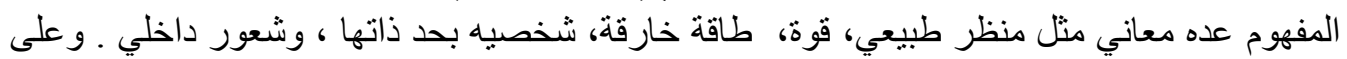
وفق ذللك، فان الهذف من هذا البحث هو تسليط الضوء على فيلى معنى الطبيعة في قصائد قصيرة مختارة

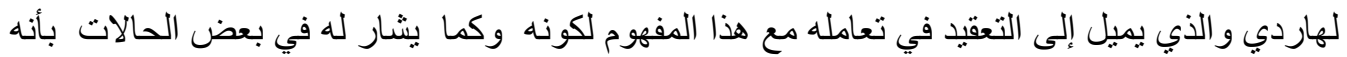

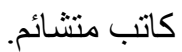

لذللك فان الموضوع يأخذ نرتيبا متدرجا وفق التسلسلات التالية: البحث يبدأ بمقدمه نوضيحية

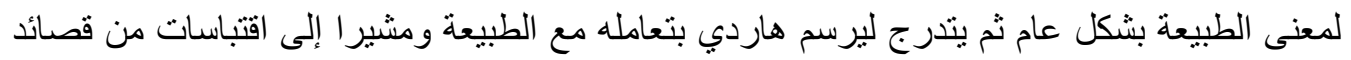

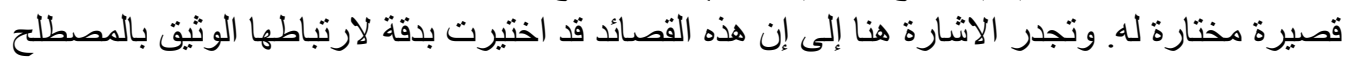

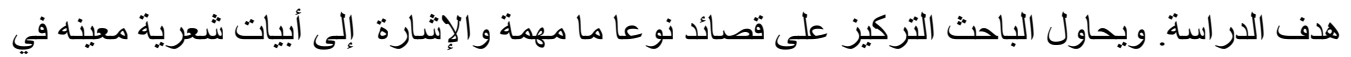

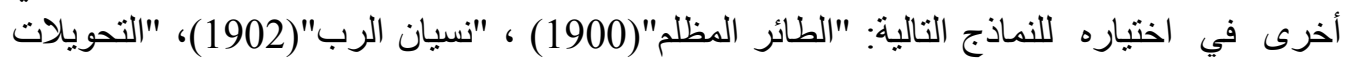

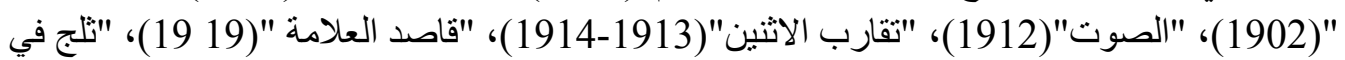

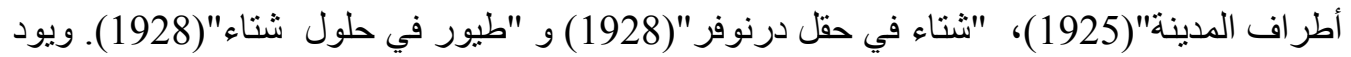

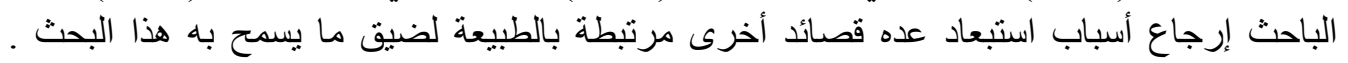

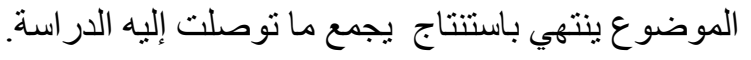

حصيلة هذه النتائج عكست اهتمام هاردي في الطبيعة والظواهر الطبيعية في الكون ـ كما انها

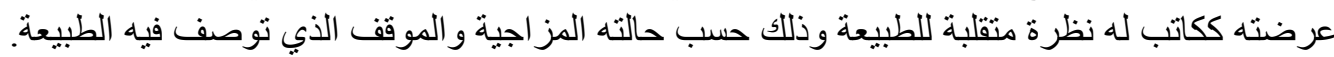

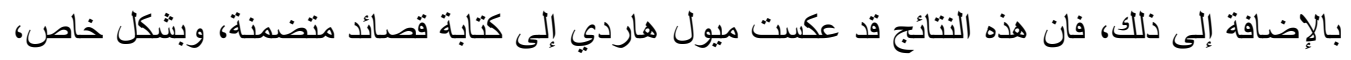

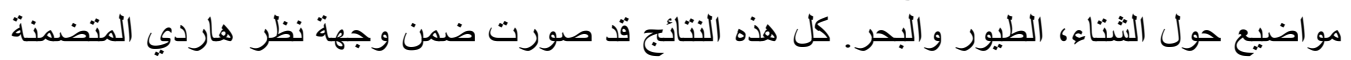
بان الطبيعة فوق كل شيء و مسيطرة على مقدرة الإنسان. 